\title{
The Role of Electronic Commercial Arbitration in the Resolution of Commercial Disputes
}

\author{
Dr. Faisal Mohammad Al-Shogairat
}

\begin{abstract}
Electronic commercial arbitration (ECA) considers as a modern mean for resolving commercial disputes that emerging due to the wide spread of electronic business transactions. Commercial work is a quick and profit-seeking, ECA is the best way to resolve commercial disputes, However, ECA is surrounding with problems and dangers, thus it requires caution and careful attending to the privacy of information in order to achieve the desired objective, and to overcome the practical and legal obstacles that may encounter.
\end{abstract}

Keywords - Arbitration, Commercial Disputes, Electronic Commercial, Electronic commercial arbitration.

\section{INTRODUCTION}

The proliferation of electronic commerce and what accompanying it of electronic commercial contracts have led to many problems in the context of what the implementation of such contracts need procedures, which have increased disputes between the parties of the modern legal association during the existence of this association and its dissolution. It is important to say that these disputes necessitated a new solutions in line with their nature in the desire to overcome the dispute related to the jurisdictional. It is fair to resolve the disputes by themselves at the will of the employers. This is known as electronic arbitration, which I would like to call it the elective judiciary as it's born out of agreement. In the view of the importance of the subject, I have examined it in this paper and reviewed the nature of the electronic commercial arbitration and, its legal nature, and the find the distinction between it and other similar legal systems, as well as the advantages and disadvantages of such type.

\section{FIRST TOPIC:}

THE NATURE OF COMMERCIAL ARBITRATION AND THE DiSTINCTION BETWEEN IT AND SIMILAR DISPUTES RESOLUTION TOOLS

- The nature of Electronic Commercial Arbitration?

The geographical boundaries between the countries now have nothing to do with technological development and what accompanying of commercial activity and daily electronic transactions that have increased to make this world a one electronic village, and increased the electronic transactions and

Dr. Faisal Mohammad Al-Shogairat, Assistant Professor, Department of Private Law, Faculty of Law, Al Hussein Bin Talal University, Jordan contracts. Thus the (electronic contract) defines as: "An agreement in which the acceptance of an open international network is met by a visual means, through the interaction between the positive and the interconnected"(1). while the concept of (cyber arbitration) was defined by some as ${ }^{(2)}$ : "Arbitration whereby parties agree to subjugate their disputes arising out of transactions that are most often concluded by electronic means to a third person to be adjudicated under an authority based on and derived from the agreement of the disputed parties, Using modern means of communication that differ from traditional methods used in traditional arbitration. There are many efforts that have contributed to the activation of the movement towards electronic arbitration. The European unit has played an active role in directing the member countries of the system to facilitate the procedures related to electronic commercial arbitration and to overcome the legislative obstacles that hinder this ${ }^{(3)}$, which indicates the importance of this work and that it is an important means of resolving disputes that is fully authentic upon parties. I refer here to indicate to the greater role played by the World Intellectual Property Organization (WIPO) in developing the electronic commercial arbitration system with what introduces of (WIPO) databases, organize this topic, and information that arbitrators benefit from, and resolving their works obstacles, in particular of what its guarantee of rapid arbitration system, the idea of the virtual judge was initiated in (1996) by professors from (Villa Nova Center For Law and Information Policy), the system supports by the American Arbitrators Association and the Cyber Sace Law Institute to develop the appropriate disputes resolution with legal and specialized expertise in arbitral matters and related laws. The virtual judge is tasked with controlling the dialogue between the parties of the dispute, to arrive at the most appropriate solution for the two parties.

1) Mohammed Ibrahim Abu Al-Haija, Electronic Commerce Contracts; Electronic Contracts, Contractual and Non-Contractual Disputes, Applicable Law, Dar Al-Thaqafa for Publishing and disruption, 2005.page (39)

2) Sami Abd al-Baki Abu Saleh, Electronic Commercial Arbitration, Comparative Study, Arab Renaissance for publishing, Cairo, page (19)

3) Article (1) from the European guidance 13/2000 " the member countries allow to information services supply and the their customers to solve their deputes excluding the courts using the technological means in the electronic world", we also mention the effort of the specialized committee in solving deputes rely on a series of directions in regard of solving deputes in the electronic line, during that the European network 
- The distinction between electronic arbitration and judicial work:

The work of the judge is a country -sponsored act with jurisdiction and is based on the law in its judgment. Whereas the work of the ordinary and electronic commercial arbitrator is a temporary voluntary action limited to only specific dispute and scope, the arbitrator is an ordinary person with a mandatory responsibility that temporary nature, his responsibility ends as Submit his decision on arbitration.

The powers of the arbitrator are broader than the judge, where he committe on the law as a source of judgment before rely on the other supported sources, but the arbitrator may rely on any other source that guarantees achievement of justice, and the public hearings of judicial session are in contrast with the secrecy of the arbitral session by easy procedures and far from slow, complication and restriction with legal procedures which characterizes the work of the judge ${ }^{(4)}$ In addition the Arbitration is preceded by judicial action, since the existence of the arbitration clause in the contract is taken away from the judicial authority and presented in the resolving of the dispute, when the will of the parties chooses the method of resolving the dispute to complete the labor department in accordance with the principle of power of the administration ${ }^{(5)}$.

\section{- The distinction between electronic arbitration} and the reconciliation ${ }^{(6)}$

Article 2044 of the French Civil Code defines the reconciliation as "a contract in which the two contracting parties resolve a dispute or a possible potential disputes" and the parties concede by conciliation about part of their claims to each other, Provides an area of dialogue and discussion between the parties of the contract to resolve the current or future dispute in the future, the reconciliation and arbitration are similar instruments for resolving the dispute in addition to the fact that the what is permissible by reconciliation cannot be permissible by arbitration. On the other hand, arbitration is aimed at reaching to a mandatory judgment without the need to make concessions from one of the parties of the disputes. However, reconciliation offers a conciliatory solution, in which no one is obliged and can make some concessions. Also the arbitration decision shall be issue by a court the decision that responsible on arbitration, this decision ends with the direct execution without the need for court sessions from the trial judge. However, reconciliation as an instrument by the parties to the dispute or the execution judge shall be a direct and indirect negotiation between the parties to the contract for the settlement of disputes or to prevent their occurrence, a

established to solve deputes directly on the line contribute in solving European customers deputes.

4) For more, see Hamad Saleh Al Yahmade, "Arbitration in Administrative Contracts", PhD thesis, Faculty of Legal, Economic and Social Sciences, Abdalmalek Al-Saadi University, Tangier, 2013/2014. Page (61) and what follow.

5) for more, see Enas Al-Khalde, Electronic Arbitration, Arab Renaissance publishing, Cairo, 2009, also see: Rafal Morak:Online Arbitration: Admissibility within the current legal frame work, p5 www.odr.info/\%20greetings.do.

6) for more see Mahmoud Mokhtar Ahmed Breire, "International Commercial Arbitration". Arab Renaissance publishing, Cairo, $3^{\text {rd }}$ Edition, 2004, page 20 and what follow. judicial ruling is required to confirm or document it, to be valid for the implementation as long as this reconciliation was not in the record of a judicial hearing session that documented throgh it. What should be noted is that electronic commercial arbitration is not permissible in disputes where it is not permissible to reconciliation.

\section{THE SECOND TOPIC:}

\section{EVALUATION OF ELECTRONIC COMMERCIAL ARBITRATION AS A DISPUTES RESOLUTION TOOL}

Some have called for the necessary to establish a court or commercial judgment specialized in contracts and disputes relating to electronic transactions that is very similar to the courts with international trait, such as the International Criminal Court or international justice court. Some even went further and tried to establish a virtual judge's court (Virtual Magistrate Project Villanova University) ${ }^{(7)}$.

A number of advantages of commercial arbitration can be presented as the following:

\section{A. Saving effort and money}

Some people are racing to save money. Electronic commercial arbitration is the best way to do this, this tool for resolving disputes does not exhaust the contractors because of the nature of the method used, which depends on sending the documents, papers and information to the electronic arbitrator, it also saving the effort that it ensure not to transfer the parties and witnesses to the arbitrator's location.

\section{$B$. The speed in resolving disputes and overcoming the disputes of jurisdiction}

One characteristic of commercial work is speed, thus the electronic commercial arbitration is the best means of achieving this. All required documents, contracts and papers are sent to the electronic arbitrator, and then they are studied with a simple and quick procedures and present solutions that ensure a quick resolution of the matter, and exceeds the law disputes matter and specify the specialist court, the Electronic Arbitration Court of the University of Montreal / Canada and the WIPO ${ }^{(8)}$ Electronic Tribunal IPO has played a major role in achieving this, as these arbitral tribunals have ensured differences concerning the determination of the applicable law and the competent court in the consideration of the dispute that may arise between the parties to the Association, particularly in the multiple jurisdictions of the contractors that made our planet as a small village and facilitated and simplified the procedures so that hundreds of thousands of transactions and commercial relations could be concluded simultaneously, as well as the technical advantage that arbitration ensures that the dispute is presented to technically and legally qualified persons in a manner that avoids the slow dispute when choosing a regular judiciary.

7) This organization was under the sponsorship of the American Villanova University, and the basic aim for it was the mediation to solve the deputes resulting from the electronic contracts by choosing one of arbitrator and give him a specialized documents and evidences thus the arbitrator solve the depute electronically.

8) Fadi Mohammed Emad Eddin, Electronic Commerce Contract, Al-Halabi Rights Publications, Beirut, $1^{\text {st }}$ Edition, page (203) 


\section{Ensure the confidentiality of work}

electronic arbitration ensures the secrecy of the dispute, thus blocking the way for the nonconcerned parties to view the matter. Respect for privacy is the title of this work. This advantage also cuts the way for competitors and enhances the chances of success between the disputesing parties, unlike some judicial systems that rely on public address for their function as ordinary judiciary. That some of those who resort to arbitration wish to lose his claim against broadcast his secrets trade in a way that affects the customer component.In addition, electronic commercial arbitration has encouraged investment and commercial activity, especially in developing countries. Many countries have modified their domestic legal systems in line with the new development and in accordance with international treaties and conventions concluded in the field of electronic commercial arbitration benefit from the advantages it creates. The legal value of arbitration is that the judge must, according to many legislations, discontinue the case when there is an arbitration clause in the contract between the parties of the dispute, as the agreement is submitted to the law not exceeding its compulsory limits and rules ${ }^{(9) .}$ The aim of this is to decrease the efforts upon courts and give the disputers opportunity to work on their choice in selecting the judge type and enjoy their advantages. We add that the electronic commercial arbitration has contributed to the alleviation of disputes over the question of law, implying duty and the competent courts in the dispute, resulting in the establishment of several international centers dealing with traditional commercial arbitration including the electronic.

However, one of the obstacles that may face the commercial arbitration and its procedures is the need to provide security in the exchange of information, details of contracts and arbitration procedures over the Internet and to address any defect in the system to enhance the concept of security and safety in the use of the modern communication network, in addition to the existence of licenses for the use of the network enables the contractors to conclude the contracts and conduct related actions, including the commercial arbitration and the necessary for the electronic signature required by this work as a way to express the will and give the arbitration binding character of the parties and the legal argument on the parties, also the protection of arbitration and its procedures against acts of piracy and fraud and all that may lead to corrupting the legal actions and the resulting effects which do not join one board, which has worsened at the present time and caused heavy losses for all sectors, and this is mitigated by the rules of the Organization International intellectual property law, and the internal international rules for the protection of property rights and other penal laws.

However, modern legislation must respond to the rapid development in the field of electronic commerce, and the need to promote relevant legislation to recognize the electronic commercial arbitration and modify the domestic laws in accordance with their specialty that differ from the ordinary commercial arbitration rules and procedures.

9) Article (109) from the Jordanian Civil Procedure.

\section{BINDING FORCE OF THE COMMERCIAL ARBITRATION DECISION}

It is necessary to question here about the extent of the binding force of the commercial arbitration decision procedure? And the extent of the need to apply the special laws to the rules related to electronic transactions and drop them on electronic arbitration procedures?

The basis of the decision of the arbitrator is his legal presumption, derived from the will of the contractors who were discharged in the contract when they agreed to resort to arbitration at the time of the dispute, including the identification of the executing agency, with the need to complete the substantive and formal conditions thereof. In addition to that referring to the electronic commercial arbitration requires to be stipulated in the contract that subject of the dispute or in an appendix to it ${ }^{(10) \text {. }}$ It's important to find that one of the is arbitration successful requirement as a mean to solve disputes is the electronic and legal culture among commercial environment and its people with tools and procedures of this arbitration in order to play its role successfully.

The electronic signature as a tool of the contractor to express its will, as well as electronic writing as the only means of conducting legal action raise practical and legal difficulties that may require the disruption of the traditional judiciary function because of the delay that does not correspond to the nature of the business requiring speed, especially it require a validation of these tools and the expertise they need; may be easy to be handled by the electronic arbitrator in such a way as to ensure verification of their validity in proof.

What should be discussed here is that the parties must agree to resort to legal arbitration and use it as a way to resolve disputes that may arise during the life of the contract between them. In addition, arbitration and its decisions must be written and signed by the arbitrators, that the laws and conventions stabilized on ${ }^{(11)}$, accordingly arbitration process should be taken into consideration all the formal and objective conditions for the provision to be valid and ready for execution in court.

It is noteworthy that many laws have assumed that arbitration is one stage of litigation. The decision of the arbitrator allowed to recourse by the highest court of the country. Thus, the Jordanian legislator did the last amendment in 2018 to the Arbitration Law of 2001, when the Court of Cassation was given the task of considering an appeal against arbitral judgments. It is therefore equal between the arbitral tribunal and the court, which is supposed to consider the dispute, and appeal of the ruling to the highest court on the judicial pyramid directly and look at as the audit only, and we find that there are many risks that may deprive the appellant interest to benefit from the advantage of considering the appeal

10) Article (1) from the arbitration and mediation system for the center under follow the World intellectual property organization (WIPO).

11) Article (31) from the special ideal law on commercial arbitration (Uncitral), and Article (54) from the organized rules for the Intellectual Property, and Article (4) from (New York) Convention. 
subject and lose the enjoyment of the advantage of gradual appeal.

Finally, the decision of the arbitral tribunal must be implemented. It is not enough to be a dead letter. Execution is the basis and the pivot of the arbitration stage and can only be achieved through the implementation which ends the dispute.

\section{REFERENCES}

[1] Enas Al-Khalde, Electronic Arbitration, Arab Renaissance publishing, Cairo, 2009.

[2] Fadi Mohammed Emad Eddin, Electronic Commerce Contract, AlHalabi Rights Publications, Beirut,1st Edition.

[3] Hamad Saleh Al Yahmade, "Arbitration in Administrative Contracts", $\mathrm{PhD}$ thesis, Faculty of Legal, Economic and Social Sciences, Abdalmalek Al-Saadi University, Tangier, 2013/2014.

[4] Mohammed Ibrahim Abu Al-Haija, Electronic Commerce Contracts; Electronic Contracts, Contractual and Non-Contractual Disputes, Applicable Law, Dar Al-Thaqafa for Publishing and disruption, 2005.

[5] Mahmoud Mokhtar Ahmed Breire, "International Commercial Arbitration". Arab Renaissance publishing, Cairo, 3rd Edition, 2004.

[6] Rafal Morak:Online Arabitration: Admissibility within the current legal frame work, p5 www.odr.info/\%20greetings.do.

[7] Sami Abd al-Baki Abu Saleh, Electronic Commercial Arbitration, Comparative Study, Arab Renaissance for publishing, Cairo,

[8] Jordanian Civil Procedure Law

[9] The special ideal Law on Commercial Arbitration (Uncitral).

[10] The world organized rules for the Intellectual Property.

[11] Convention on the Recognition of the Foreign Arbitral decisions (New York 1958). 